\title{
Seasonal Incidence of Insect Pests and Their Biocontrol Agents on Soybean
}

\author{
Harish Kumar Netam, Dr. Rajeev Gupta and Shivam Soni \\ Department of Entomology Indira Gandhi Krishi Vishwavidyalaya, Raipur (C.G.), India
}

\begin{abstract}
Seasonal incidence of insect pests of soybean will be recorded from field during kharif 2010. Soybean variety JS-93-05 will be sown on $3^{\text {th }}$ July 2010. In this experiment numbers of plants infested by girdle beetle and the number of caterpillar pests and natural enemies will be counted from ten randomly selected places (in one meter row-length ). to record the observations on sucking pests, insect population will be recorded from randomly selected twenty plants on which five leaves taken three from upper and two from bottom in each at ten days interval.

During the course of study, five insects species, viz., Girdle beetle, Obereopsis brevis tobacco caterpillar, Spodoptera litura, green semilooper, Chryrodecxis acuta, Jassids, Empoasca kerri and white flies, Bemisia tabaci were recorded as the major pests on soybean, variety JS 93-05 causing damage at various stages of the crop. All these insects made their first appearance on the crop to a greater or lesser extent in the last week of July. The activity of girdle beetle increased gradually with peak density of the cerambycid in the last week of August recoding 3.2 damaged plants per meter row with seasonal mean of 1.73 damaged plants. The density of lepidopterous caterpillars increased gradually with peak population of 5.0 larvae per meter row during the last week of August and seasonal mean of 3.22 larvae per meter row among the sucking pests, whitefly was observed in higher numbers than jassids. The peak density of sucking pests was observed during third week of September with 4.4 sucking pests/plant and seasonal mean of 3.62 white flies and jassids per plant.

Preying upon the sucking Insects, were two species of lady bird beetle, Coccinella septumpunctata and Menochilus sexmaculata and two species of spiders, lynx spider and an unidentified golden preying spider. The latter was also a recorded preying on lepidopterous larvae. A predatory pentatomid bug, Eocanthecona furcellata was observed sucking the body sap of lepidopterous larvae, there existed a positive but nonsignificant correlation between lepidopterous larvae and predators and between sucking pests and predatory fauna with ' $r$ ' values 0.545 and 0.798 , respectively.

(KeyWords: bio agents, girdle beetle, Population dynamics,seasonal incidence, soybean eco system, lepidopteran, sucking pest)

1. Student of M.Sc.(Ag), Department of Entomology

2. Professor, Department of Entomology
\end{abstract}

\section{Introduction:-}

Soybean is a wonder crop of twentieth century. It is an excellent source of protein and oil. It is a two dimensional crop as it contains about 40-42 per cent high quality protein and 20-22 per cent oil. It also contains 20-30 per cent carbohydrates. The protein quality of soybean is equivalent to that of meat, milk products and eggs. Hence, it is well established fact that soybean is cheap source of protein and edible oil. These characteristics have made soybean to fit well in sustainable agriculture. During the late sixties and early seventies, the soybean crop was considered to be comparatively safe crop as regards to insect pest attack. However, Gangrade (1976) reported over 99 insect species attacking soybean crop at Jabalpur.but now the situation has changed and as many as 275 insect species have been recorded attacking soybean crop in India. Researchers in many parts of India have confirmed that seed yield and seed quality are being adversely affected by major insect pests viz. girdle beetle, tobacco caterpillar, green semilooper, Helicoverpa armigera, jassids and white fly.

\section{Material And Methods}

Seasonal incidence of insect pests of soybean was recorded at 10 days interval from field during kharif, 2010.Soybean variety JS-93-05 was sown on $3^{\text {th }}$ July 2010. In this experiment number of plants infested by girdle beetle and the number of caterpillar pests and natural enemies was counted from ten randomly selected one meter row-length. To record the observations on sucking pests, insect population was recorded from randomly selected twenty plants from each plant, insect count was recorded from five leaves, three from upper and two from middle part of the plant. 


\section{Result And Discussion:-}

The studies on the seasonal incidence of insect pests of soybean crop on variety JS-93-05 revealed that the occurrence of insect pest complex commenced from 25 days of sowing. Observation of pest incidence i.e. population of each insect was recorded on soybean crop as per the procedure mentioned under "Materials and Methods." During the course of study, five insect species, viz., Girdle beetle, tobacco caterpillar, green semilooper, whiteflies and jassids were observed causing damage at various growth stages of soybean crop. Among the bio control agents, three predators, namely, lady bird beetles, spiders and a predatory pentatomid bug were mainly observed preying on them(Table $1.1 \& 1.2$ ).

Table 1.1:- Insect pests fauna observed on Soybean variety JS 93-05 during Kharif, 2010.

\begin{tabular}{|c|c|c|c|c|c|}
\hline S.No. & Common Name & Systemic position & $\begin{array}{l}\text { Damaging } \\
\text { Stage }\end{array}$ & $\begin{array}{l}\text { Range of } \\
\text { incidence }\end{array}$ & $\begin{array}{l}\text { Status of peak } \\
\text { activity }\end{array}$ \\
\hline 1. & Girdle beetle & $\begin{array}{c}\text { Obereopsis brevis } \\
\text { (Coleoptera : } \\
\text { Cerambycidae) }\end{array}$ & Grub & $\begin{array}{c}0.8 \text { to } 3.2 \\
\text { (Grubs / m. row) }\end{array}$ & $\begin{array}{l}\text { Last week of } \\
\text { August }\end{array}$ \\
\hline 2. & $\begin{array}{l}\text { Tobacco } \\
\text { caterpillar }\end{array}$ & $\begin{array}{c}\text { Spodoptera litura } \\
\text { (Lepidoptera : Noctuidae) }\end{array}$ & Caterpillar & $\begin{array}{c}1.3 \text { to } 3.7 \\
\text { (Caterpillars / m. } \\
\text { row) }\end{array}$ & $\begin{array}{l}\text { Last week of } \\
\text { August }\end{array}$ \\
\hline 3. & $\begin{array}{c}\text { Green } \\
\text { semilooper }\end{array}$ & $\begin{array}{c}\text { Chrysodecxis acuta } \\
\text { (Lepidoptera : Noctuidae) }\end{array}$ & Caterpillar & $\begin{array}{c}0.5 \text { to } 1.3 \\
\text { (Caterpillars / m. } \\
\text { row) }\end{array}$ & $\begin{array}{l}\text { Last week of } \\
\text { August }\end{array}$ \\
\hline 4. & White fly & $\begin{array}{c}\text { Bemisia tabaci } \\
\text { (Hemiptera : Aleyrodidae) }\end{array}$ & $\begin{array}{l}\text { Nymph and } \\
\text { Adult }\end{array}$ & $\begin{array}{c}1.3 \text { to } 3.6 \\
\text { (flies / plant) }\end{array}$ & $\begin{array}{c}\text { Third week of } \\
\text { September }\end{array}$ \\
\hline 5. & Jassids & $\begin{array}{c}\text { Empoasca kerri } \\
\text { (Hemiptera : Cicadellidae) }\end{array}$ & $\begin{array}{l}\text { Nymph and } \\
\text { Adult }\end{array}$ & $\begin{array}{c}0.6 \text { to } 1.1 \\
\text { (Jassids / plant) }\end{array}$ & $\begin{array}{c}\text { Third week of } \\
\text { August }\end{array}$ \\
\hline
\end{tabular}

Table 1.2:- Predatory fauna observed on insect pests of Soybean variety JS 93-05 during Kharif, 2010.

\begin{tabular}{|c|c|c|c|c|c|}
\hline $\begin{array}{l}\text { S. } \\
\text { No. }\end{array}$ & Common name & Systemic Position & Insect Pests Preyed & $\begin{array}{l}\text { Range of } \\
\text { incidence }\end{array}$ & $\begin{array}{c}\text { Status of } \\
\text { Peak } \\
\text { Activity }\end{array}$ \\
\hline 1. & Lady bird beetle- & $\begin{array}{l}\text { a) Menochilus } \\
\text { sexmuculata } \\
\text { b) Coccinella } \\
\text { septumpunctata } \\
\text { (Coleopteran : } \\
\text { Coccinellidae ) }\end{array}$ & $\begin{array}{l}\text { Whiteflies and } \\
\text { jassids } \\
\text { Whiteflies and } \\
\text { jassids }\end{array}$ & $\begin{array}{c}0.2 \text { to } 0.9 \\
\text { (Beetles/meter } \\
\text { row) }\end{array}$ & $\begin{array}{l}\text { Third week } \\
\text { of } \\
\text { September }\end{array}$ \\
\hline 2. & \begin{tabular}{l}
\multicolumn{1}{c}{ Spiders - } \\
(a) $\quad$ Lynx \\
spider \\
(b)Golden preying \\
\multicolumn{2}{c}{ spider }
\end{tabular} & $\begin{array}{c}\text { Oxyopes satticus } \\
\text { (Araneae : Oxyopidae) } \\
\text { Unidentified }\end{array}$ & $\begin{array}{l}\text { Whiteflies and } \\
\text { jassids } \\
\text { Lepidopterous } \\
\text { caterpillars }\end{array}$ & $\begin{array}{c}0.2 \text { to } 0.7 \\
\text { (Spiders/meter } \\
\text { row) }\end{array}$ & $\begin{array}{l}\text { Third week } \\
\text { of } \\
\text { September }\end{array}$ \\
\hline 3. & Pentatomid bug & $\begin{array}{l}\text { Eocanthecona } \\
\text { furcellata } \\
\text { (Hemiptera: } \\
\text { Pentatomidae) }\end{array}$ & $\begin{array}{l}\text { Lepidopterous } \\
\text { caterpillars }\end{array}$ & $\begin{array}{l}0.2 \text { to } 1.1 \\
\text { (bugs/meter } \\
\text { row) }\end{array}$ & $\begin{array}{c}\text { Second } \\
\text { week of } \\
\text { September }\end{array}$ \\
\hline
\end{tabular}

Pest Succession Studies : During the course of study, five insects species, viz., Girdle beetle, Obereopsis brevis tobacco caterpillar, Spodoptera litura, green semilooper, Chryrodecxis acuta, Jassids, Empoasca kerri and white flies, Bemisia tabaci were recorded as the major pests on soybean, variety JS 93-05 causing damage at various stages of the crop. All these insects made their first appearance on the crop to a greater or lesser extent in the last week of July. The activity of girdle beetle increased gradually with peak density of the cerambycid in the last week of August recoding 3.2 damaged plants per meter row with seasonal mean of 1.73 damaged plants. The density of lepidopterous caterpillars increased gradually with peak population of 5.0 larvae per meter row during the last week of August and seasonal mean of 3.22 larvae per meter row among the sucking pests, whitefly was observed in higher numbers than jassids. The peak density of sucking pests was observed during third week of September with 4.4 sucking pests/plant and seasonal mean of 3.62 white flies and jassids per plant.

Preying upon the sucking Insects, were two species of lady bird beetle, Coccinella septumpunctata and Menochilus sexmaculata and two species of spiders, lynx spider and an unidentified golden preying spider. The latter was also a recorded preying on lepidopterous larvae. A predatory pentatomid bug, Eocanthecona furcellata was observed sucking the body sap of lepidopterous larvae, there existed a positive but non- 
significant correlation between lepidopterous larvae and predators and between sucking pests and predatory fauna with 'r' values 0.545 and 0.798 , respectively, (Table 1.3).

Table 1.3: Seasonal incidence of major insect pests and predators on soybean variety JS-93-05 during kharif, 2010

\begin{tabular}{|c|c|c|c|c|c|c|c|c|}
\hline \multirow[b]{2}{*}{$\begin{array}{c}\text { Data of } \\
\text { observation }\end{array}$} & \multicolumn{3}{|c|}{ Incidence/meter row length } & \multicolumn{2}{|c|}{ Mean population/plant } & \multicolumn{3}{|c|}{$\begin{array}{c}\text { No. of predators/ meter rov } \\
\text { length }\end{array}$} \\
\hline & $\begin{array}{c}\text { damaged } \\
\text { plants by } \\
\text { Obereopsis } \\
\text { brevis }\end{array}$ & $\begin{array}{c}\text { Spodop } \\
\text { tera } \\
\text { litura }\end{array}$ & $\begin{array}{c}\text { Chrysod } \\
\text { ecxis } \\
\text { Acuta }\end{array}$ & $\begin{array}{c}\text { Bemisia } \\
\text { tabaci }\end{array}$ & $\begin{array}{c}\text { Empoasca } \\
\text { kerri }\end{array}$ & $\begin{array}{c}\text { Cocci } \\
\text { nellid } \\
\text { beetle } \\
\text { s }\end{array}$ & $\begin{array}{c}\text { Spid } \\
\text { ers }\end{array}$ & $\begin{array}{c}\text { Pentatomid } \\
\text { bug }\end{array}$ \\
\hline $29 / 07 / 2010$ & 0.8 & 1.3 & 0.7 & 1.5 & 1.0 & 0.2 & 0.3 & 0.2 \\
\hline $08 / 08 / 2010$ & 1.2 & 1.6 & 0.8 & 2.2 & 0.6 & 0.3 & 0.2 & 0.2 \\
\hline $18 / 08 / 2010$ & 1.7 & 2.1 & 0.5 & 2.5 & 1.1 & 0.2 & 0.5 & 0.3 \\
\hline $28 / 08 / 2010$ & 3.2 & 3.7 & 1.3 & 3.2 & 1.0 & 0.3 & 0.4 & 0.6 \\
\hline $08 / 09 / 2010$ & 2.2 & 3.4 & 1.1 & 3.2 & 0.9 & 0.9 & 0.6 & 1.1 \\
\hline $18 / 09 / 2010$ & 1.5 & 2.4 & 0.5 & 3.6 & 0.8 & 0.9 & 0.7 & 0.7 \\
\hline $\begin{array}{l}\text { Seasonal } \\
\text { mean }\end{array}$ & 1.73 & 2.41 & 0.81 & 2.74 & 0.88 & 0.47 & 0.45 & 0.52 \\
\hline
\end{tabular}

1.1.5 Influence of weather parameters on major pests of soybean. ～(Table 1.4- 1.7)

The influence of different weather parameters viz maximum and minimum temperature, morning and evening relative humidity and rainfall on the seasonal incidence of caterpillar pests and girdle beetle based on the number of larvae and girdle beetles infested plants in randomly selected ten one meter row lengths and sucking pests based on the population/plant from 20 randomly selected plants was observed by working out correlation coefficient (r) and regression equation, $\mathrm{Y}=\mathrm{a}+\mathrm{bx}$.

Table 1.4 :- Seasonal Incidence of Lepidopterous larvae (S. litura \& $C$. acuta) as influenced by different weather parameters on Soybean during kharif,2010.

\begin{tabular}{|c|c|c|c|c|c|c|c|}
\hline \multirow[b]{2}{*}{ S. No. } & \multirow[b]{2}{*}{$\begin{array}{c}\text { Date of } \\
\text { Obersvatio } \\
\mathbf{n}\end{array}$} & \multirow{2}{*}{$\begin{array}{c}\text { No. of } \\
\text { Lepidopterous } \\
\text { larvae/meter row }\end{array}$} & \multicolumn{2}{|c|}{ Temperature $\left({ }^{0} \mathrm{C}\right)$} & \multicolumn{2}{|c|}{ Average RH(\%) } & \multirow[b]{2}{*}{$\begin{array}{c}\text { Rainfal } \\
(\mathbf{m m})\end{array}$} \\
\hline & & & Max & Min. & Morning & $\begin{array}{c}\text { Evenin } \\
\mathbf{g}\end{array}$ & \\
\hline 1. & $29 / 07 / 2010$ & 2.0 & 30.3 & 25.6 & 91 & 78 & 277.8 \\
\hline 2. & $08 / 08 / 2010$ & 2.4 & 30.1 & 24.9 & 92 & 71 & 41.2 \\
\hline 3. & $18 / 08 / 2010$ & 2.6 & 31.9 & 26.0 & 92 & 70 & 8.4 \\
\hline 4. & $28 / 08 / 2010$ & 5.0 & 30.3 & 25.2 & 94 & 82 & 30.0 \\
\hline 5. & 08/09/2010 & 4.5 & 31.7 & 25.0 & 94 & 72 & 129.6 \\
\hline 6. & $18 / 09 / 2010$ & 2.9 & 32.2 & 24.5 & 92 & 64 & 51.0 \\
\hline & & $\begin{array}{l}\text { Correlation co- } \\
\text { efficient }(r)\end{array}$ & 0.051 & -0.247 & $0.977 *$ & 0.389 & -0.295 \\
\hline
\end{tabular}

Table 1.5:- Seasonal Incidence of girdle beetle $(O$. brevis) as influenced by different weather parameters on Soybean during kharif,2010.

\begin{tabular}{|c|c|c|c|c|c|c|c|}
\hline \multirow[b]{2}{*}{ S. No. } & \multirow[b]{2}{*}{$\begin{array}{c}\text { Date of } \\
\text { obersvation }\end{array}$} & \multirow[b]{2}{*}{$\begin{array}{l}\text { Number of girdle } \\
\text { beetle damaged } \\
\text { plants /meter row }\end{array}$} & \multicolumn{2}{|c|}{ Temperature $\left({ }^{\circ} \mathrm{C}\right)$} & \multicolumn{2}{|c|}{ Average RH (\%) } & \multirow[b]{2}{*}{$\begin{array}{c}\text { Rainfall } \\
(\mathbf{m m})\end{array}$} \\
\hline & & & Max & Min. & $\begin{array}{c}\text { Mornin } \\
\text { g }\end{array}$ & $\begin{array}{c}\text { Evenin } \\
\mathrm{g}\end{array}$ & \\
\hline 1. & $29 / 07 / 2010$ & 0.8 & 30.3 & 25.6 & 91 & 78 & 277.8 \\
\hline 2. & $08 / 08 / 2010$ & 1.2 & 30.1 & 24.9 & 92 & 71 & 41.2 \\
\hline 3. & $18 / 08 / 2010$ & 1.7 & 31.9 & 26.0 & 92 & 70 & 8.4 \\
\hline 4. & $28 / 08 / 2010$ & 3.2 & 30.3 & 25.2 & 94 & 82 & 30.0 \\
\hline 5. & $08 / 09 / 2010$ & 2.2 & 31.7 & 25.0 & 94 & 72 & 129.6 \\
\hline 6. & $18 / 09 / 2010$ & 1.5 & 32.2 & 24.5 & 92 & 64 & 51.0 \\
\hline & & $\begin{array}{l}\text { Correlation co- } \\
\text { efficient (r) }\end{array}$ & 0.220 & -0.250 & $0.959 *$ & 0.254 & -0.373 \\
\hline
\end{tabular}


Table 1.6:- Seasonal Incidence of Sucking pests (B. tabaci \& $E$. kerri) as influenced by different weather parameters on Soybean during kharif,2010.

\begin{tabular}{|c|c|c|c|c|c|c|c|}
\hline \multirow[b]{3}{*}{ S. No. } & \multirow[b]{3}{*}{$\begin{array}{c}\text { Date of } \\
\text { obersvation }\end{array}$} & \multirow[b]{3}{*}{$\begin{array}{c}\text { No. of } \\
\text { sucking } \\
\text { pests/plant }\end{array}$} & \multirow{2}{*}{\multicolumn{2}{|c|}{ Temperature $\left({ }^{\circ} \mathrm{C}\right)$}} & \multirow{2}{*}{\multicolumn{2}{|c|}{ Average RH(\%) }} & \multirow[b]{3}{*}{$\begin{array}{c}\text { Rainfall } \\
(\mathbf{m m})\end{array}$} \\
\hline & & & & & & & \\
\hline & & & Max & Min. & Morning & Evening & \\
\hline 1. & $29 / 07 / 2010$ & 2.5 & 30.3 & 25.6 & 91 & 78 & 277.8 \\
\hline 2. & $08 / 08 / 2010$ & 2.8 & 30.1 & 24.9 & 92 & 71 & 41.2 \\
\hline 3. & 18/08/2010 & 3.6 & 31.9 & 26.0 & 92 & 70 & 8.4 \\
\hline 4. & $28 / 08 / 2010$ & 4.2 & 30.3 & 25.2 & 94 & 82 & 30.0 \\
\hline 5. & 08/09/2010 & 4.1 & 31.7 & 25.0 & 94 & 72 & 129.6 \\
\hline 6. & $18 / 09 / 2010$ & 4.4 & 32.2 & 24.5 & 92 & 64 & 51.0 \\
\hline & & $\begin{array}{c}\text { Correlation } \\
\text { co-efficient } \\
(\mathbf{r})\end{array}$ & 0.638 & -0.410 & 0.685 & -0.249 & - 0.540 \\
\hline
\end{tabular}

Table 1.7:- Influence of predatory fauna on the incidence of lepidopterous and sucking pests infesting soybean during kharif, 2010.

\begin{tabular}{|c|c|c|c|c|}
\hline \multirow[b]{2}{*}{$\begin{array}{c}S . \\
\text { No. }\end{array}$} & \multirow[b]{2}{*}{$\begin{array}{c}\text { Data of } \\
\text { Observation }\end{array}$} & \multicolumn{3}{|c|}{ No. of insects pests per meter row length } \\
\hline & & Predators & $\begin{array}{l}\text { Lepidopterous } \\
\text { larvae }\end{array}$ & Sucking pests \\
\hline 1. & 29/07/2010 & 0.7 & 2.0 & 2.5 \\
\hline 2. & 08/08/2010 & 0.7 & 2.4 & 2.8 \\
\hline 3. & 18/08/2010 & 1.0 & 2.6 & 3.6 \\
\hline 4. & $28 / 08 / 2010$ & 1.3 & 5.0 & 4.2 \\
\hline 5. & 08/09/2010 & 2.6 & 4.5 & 4.1 \\
\hline 6. & 18/09/2010 & 2.3 & 2.9 & 4.4 \\
\hline & & $\begin{array}{l}\text { rrelation } \\
\text { efficient (r) }\end{array}$ & 0.545 & 0.798 \\
\hline
\end{tabular}

Girdle beetle, lepidopterous caterpillars and sucking pests were first observed on the crop during last week of July which was associated with $30.3^{\circ} \mathrm{C}$ and $25.6^{\circ} \mathrm{C}$ maximum and minimum temperatures, 91 and 78 percent morning and evening relative humidity and $277.8 \mathrm{~mm}$ rainfall. Peak activity of girdle beetle (3.7 damaged plants/ $\mathrm{m}$ row) and lepidopterous larvae (5.0 larvae/ $\mathrm{m}$ row) observed during last week of August was associated with minimum and maximum temperatures of $30.3^{\circ} \mathrm{C}$ and $25.2^{\circ} \mathrm{C}$, morning and evening relative humidity of 94 and 82 percent and $30.0 \mathrm{~mm}$ rainfall. The peak activity of sucking pests was recorded during third week of September which was associated with $32.2^{\circ} \mathrm{C}$ maximum and $24.5^{\circ} \mathrm{C}$ minimum temperature, $92 \%$ morning and $64 \%$ evening relative humidity and $51.0 \mathrm{~mm}$ rainfall.

Fig 1.1 :- Regression of lepidopterous larval population on Morning Relative Humidity.

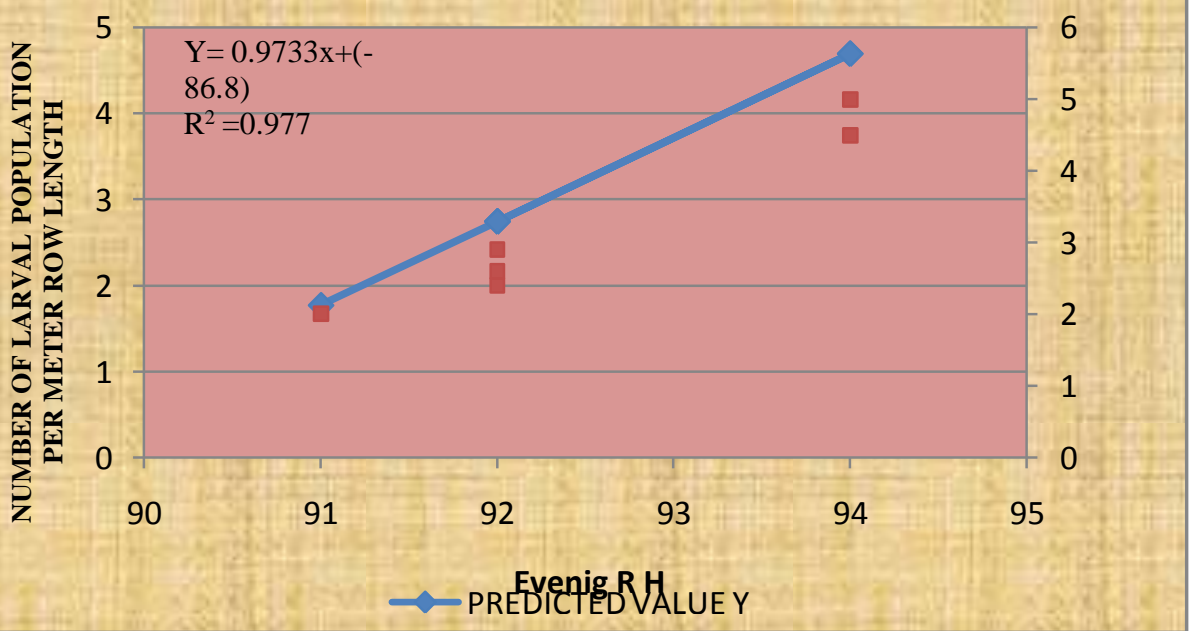


FIG 1.2:- Regression of Girdle beetle population on Morning Relative Humidity.

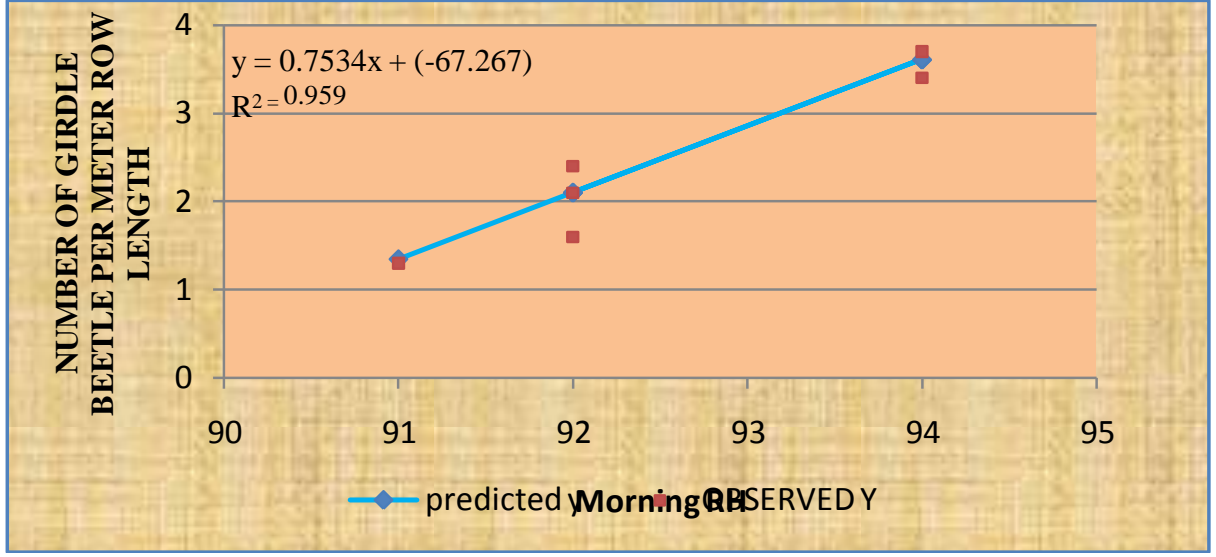

There existed a significantly positive co-rrelation between lepidopterous larvae and relative humidity of the morning with ' $r$ ' value 0.977 and regression equation $y=0.9733 x+(-86.8)$. Similarly, girdle beetle incidence was significantly positively co-rrelated with morning relative humidity having ' $r$ ' value 0.959 and regression equation $\mathrm{y}=0.7534 \mathrm{x}+(-67.267)$.

Joshi and Patel (2010) also observed non-significant relationship between the insect pest population and the ambient weather.

\section{Conclusion}

Girdle beetle, $O$. brevis, tobacco caterpillar, S. litura, green semilooper, $C$. acuta, whitflies, B. tabaci and jassids, E. kerri were observed as the major pest on soybean variety JS-93-05. The peak activity of girdle beetle (3.2 damaged plants $/ \mathrm{m}$ row) and lepidopterous larvae (5.0 larvae/m row) was recorded during last week of August and that of sucking pests (4.4 insects/plant) during third week of September.

Two species of lady bird beetle, $C$. septumpunctata and $M$. sexmaculata and two predatory spidersLynx spider and golden predatory spider were found predating mainly on jassids and whiteflies. A predatory pentatomid bug, E. furcellata was noticed sucking the body sap of lepidopterous larvae. There existed a positive but non-significant co-relation between caterpillar pests and predators $(\mathrm{r}=0.545)$ and between sucking pests and predatory fauna $(\mathrm{r}=0.798)$

There existed a significantly positive co-rrelated between lepidopterous larvae and morning relative humidity $[\mathrm{r}=0.977$; regression equation $\mathrm{y}=0.9733 \mathrm{x}+(-86.8)]$ and between girdle beetle and morning relative humidity $(\mathrm{r}=0.959)$; regression equation $\mathrm{y}=0.7534 \mathrm{x}+(-67.267)$.

\section{Reference}

[1] Didonet, J., Fragoso, D. B., Peluzio, J.M and Santos, G.R. (2003). Population dynamics of soybean pests and their natural ene mies in Rio Formoso Project - Formoso do Araguaia - TO, Brazil. Acta Amazonica. 28(1): 67-74.

[2] Feng, Hongqiang., Fred Gould., Yunxin Huang., Yuying Jiang and Kongming Wu. (2010). Modeling the Population Dynamics of Cotton Bollworm Helicoverpa Armigera (Hübner) (Lepidoptera: Noctuidae) over a Wide Area in Northern China. Ecological Modelling. 221(15): 1819-1830.

[3] Gangrade, G.A. (1976) Terminal Technical Report on The Project "Assessment of effects on yield and quality of soybean caused by major arthropod pests", Deptt. of Ent. , J. N. Agril., univ. , Jabalpur, 143 pp.

[4] Joshi, M.D. and Patel, V.N. (2010). Seasonal Incidence of Leaf Miner Aproaerema modicella Deventer on Soybean. Agril. Sci. Dig. 30(3):236-239.

[5] Mohamed, A. A., Abdel-Moniem, A. S. H. S. and Mahmoud, O. (2009). Determination of Resistance Status of Experimental Soybeans to the Lima Bean Pod Borer, Etiella zinckenella Treitschke and the Whitefly, bemisia tabaci Gennadius at El-Dakhla Oases, New Valley, Egypt. Archives of Phytopathology and Plant Protection, 42(6): 552-558.

[6] Patil, R.H. (2002). Evaluation of insect pest management components in soybean eco system. Ph.D. Thesis, Univ. Agric. Sci., Dharwad, p. 166.

[7] Singh, O.P., Singh, K.J and Singh, P.P. (2000). Effect of different varieties of soybean and their plant population on the incidence of grey semilooper, Rivula sp in Madhya pradesh. Bharatiya Krishi Anusandhana Patrika, 4(3): 149-153.

[8] Van den Berg, H., Aziz, A. and Machrus, M. (2000) On-farm Evaluation of Measures to Monitor and Control Soybean Pod-borer Etiella Zinckenella in East Java, Indonesia. International Journal of Pest Management, 46(3):219-224. 